\title{
The Relationship between Social Justice Leadership and Organizational Citizenship Behaviours
}

\author{
Bayram BOZKURT ${ }^{*}$ \\ Educational Science, Gaziantep University, Gaziantep, Turkey
}

ORCID: 0000-0002-9184-0878

\begin{tabular}{|c|c|}
\hline Article history & th \\
\hline $\begin{array}{l}\text { Received: } \\
02.03 .2021\end{array}$ & $\begin{array}{l}\text { justice leadership behaviours on teachers' organizational citizenship } \\
\text { behaviours based on teachers' perceptions. The predictive correlational }\end{array}$ \\
\hline $\begin{array}{l}\text { Received in revised form: } \\
16.08 .2021\end{array}$ & $\begin{array}{l}\text { research design, one of the correlational research methods, was used in } \\
\text { the study. It was carried out with the participation of } 1025 \text { teachers } \\
\text { working at public secondary schools in Gaziantep city centre. Research }\end{array}$ \\
\hline $\begin{array}{l}\text { Accepted: } \\
24.08 .2021\end{array}$ & $\begin{array}{l}\text { data were collected using the Social Justice Leadership Scale and the } \\
\text { Organizational Citizenship Behaviour Scale. SPSS } 22.0 \text { and AMOS } 21\end{array}$ \\
\hline Key words: & software packages were used to analyze the data. The obtained data were \\
\hline $\begin{array}{l}\text { Social justice; } \\
\text { Social justice leadership; } \\
\text { Organizational citizenship } \\
\text { behaviour, } \\
\text { Structural equation modeling. }\end{array}$ & $\begin{array}{l}\text { analysed through descriptive statistics (mean, standard deviation, and } \\
\text { others.), Pearson's correlation, and structural equation modeling. It was } \\
\text { determined that social justice leadership and organizational citizenship } \\
\text { behaviours were exhibited at higher levels by school administrators and } \\
\text { teachers consecutively. There was a moderate, positive, and significant } \\
\text { relationship between organizational citizenship behaviours and social } \\
\text { justice leadership and its sub-dimensions of critical awareness, } \\
\text { stakeholder support, participation, and distributive justice. Structural } \\
\text { equation modeling yielded that social justice leadership behaviours } \\
\text { positively predicted the organizational citizenship behaviours of teachers } \\
\text { and social justice leadership explained } 37 \% \text { of the variance in } \\
\text { organizational citizenship behaviours. It can be claimed that teacher } \\
\text { performance would increase upon adopting and enhancing social justice- } \\
\text { based practices in school settings. }\end{array}$ \\
\hline
\end{tabular}

\section{Introduction}

Incremental differentiation in the social structure of countries caused by globalization has revealed the need for the adoption of different approaches both during educational procedures and in educational administration (Falk, 2003; White \& Cooper, 2014). Accordingly, the countries are supposed to organize their educational policies in a way to eliminate inequality and injustice likely to arise. In this regard, educational policies should be based on values such as justice, equality, and solidarity (Şişman, 2006).

Social differentiation in organizations may emerge due to the rapid population movements both between and within the countries. It is inevitable for educational organizations to be affected

\footnotetext{
*Correspondency: byrmbzkrt02@gmail.com
} 
by such kind of a situation. Gewirtz \& Cribb (2002) voiced that the educational policies of countries and the practices in educational institutions should take place within the framework of social justice. Schools are composed of individuals with different qualities and characteristics such as cultural identity, ethnicity, gender, language, religion, socioeconomic status, worldview, and having disabilities or not. It can be asserted that the elimination of social imbalance and injustice among the actors of school society would be effective in achieving school goals. The importance of school administrators' social justice leadership skills becomes even clearer for the effectiveness of school practices.

As being social justice leaders, school administrators should ensure all the stakeholders benefit from the training facilities in a fair way especially for the teachers who are the practitioners of education. Thus, it can be alleged that teachers' perceptions and behaviours would be shaped by school administrators' social justice leadership. Teachers with a positive perception of social justice leadership are supposed to behave above and beyond the expectations to achieve school goals. Chen (2008) asserted that teachers would behave positively, work collaboratively, and trust their superiors with increased loyalty and decreased negative behaviours in the event that their superiors adopted justice-based practices. Teachers, as the practitioners of education, play the most important role in attaining school objectives in the context of social justice in education (Bogotch \& Shields, 2014). However, teachers' perceptions of social justice depend on administrative practices (Brown, 2004; Marshall, 2004) Therefore, school administrators have significant responsibilities as being social justice leaders.

It is possible to come across several studies related to social justice leadership (Bozkurt, 2017; Özdemir \& Kütküt, 2015; Özdemir \& Pektaş, 2017) in literature in Turkey, but no specific study examining the relationship between social justice leadership and organizational citizenship behaviours at schools could be found. Thus, the effect of social justice leadership behaviours of secondary school administrators on the organizational citizenship behaviours of teachers was investigated in the present study based on teachers' perceptions. Below, the conceptual framework for social justice leadership and organizational citizenship behaviours was given before introducing the research problems.

\section{Social Justice Leadership}

The social justice leadership behaviours of school administrators have started to attract the attention of researchers with the development of the phenomenon of social justice in the field of educational sciences since the mid-1900s (Bozkurt, 2017; Furman \& Sheild, 2005; JeanMarie, 2008; Oplatka, 2010; Özdemir \& Kütküt, 2015; Özdemir \& Pektaş, 2017; Theoharis, 2007). It can be asserted that the studies on educational administration and leadership mostly focused on the characteristics, types, dimensions, and contextuality of leadership (Bass, 1999; Conger \& Kanungo, 1988; Greenleaf, 1977; Yukl, 2010). On the other hand, social justice leadership has begun to come into prominence based on the criticism that the social dimension of leadership has been neglected. The belief that schools lay the foundations of values such as equality, justice, and solidarity has also aroused interest in social justice leadership.

Various definitions of social justice leadership could be found in the relevant literature (Brooks, Jean-Marie, Normore, \& Hodgins, 2007; Marshall \& Olivia, 2006; Theoharis, 2007; Wasonga, 2009). Social justice leadership has been discussed on the basis of critical approaches including social justice and leadership, feminism, African American and Latin leadership styles (McCabe \& McCarthy, 2005). Marshall \& Olivia (2006) defined social justice leadership as a leadership approach aimed at improving the achievement of minorities, economically disadvantaged 
individuals, women, and homosexuals who have traditionally failed at schools. In his study on the theory of social justice leadership, Theoharis (2007) described social justice educational leaders as vision holders who eliminate the problems based on the differences of race, class, gender, sexual preference, and other historically marginalizing factors. Brooks et al. (2007) defined social justice leaders as transformational and critical activists who create connections between social actors by pointing out that social justice leadership is an elusive process depending on the context over time. Wasonga (2009) explained social justice leadership as a leadership approach enabling participation in the decision-making process, requiring passionate commitment, collaboration with different groups in society, and supporting social change efforts on the basis of justice.

The literature on the conceptual explanation and classification of social justice leadership makes it possible to discover different dimensions. In her study on the framework of social justice leadership, Furman (2012) classified five dimensions of social justice leadership: personal, interpersonal, social, systemic, and ecological. Özdemir \& Kütküt (2015) categorized the social justice leadership dimensions as critical awareness, support, and participation in their scale development study to measure the social justice leadership behaviours of school administrators. Bozkurt (2017) organized the social justice leadership behaviours of secondary school administrators in four dimensions based on teachers' opinions: critical awareness, stakeholder support, participation, and distributive justice. As for stakeholder support, Bozkurt (2017) specified that school administrators should make an effort for all stakeholders (students, teachers, auxiliary staff, and alike .) to benefit from the training facilities for an effective school. He also pointed out that the students with disabilities from lower socioeconomic status should be supported to have access to education and teacher qualifications should be improved. Freire (2004) explained the critical awareness dimension of social justice leadership as being aware of social, economic, and political pressures and paradoxes and superiors' taking action against them. The distributive justice dimension has been identified by Rawls's theory of justice. Rawls (1993) clarified distributive justice as the fair distribution of institutional resources, positions, and duties for the benefit of all. In terms of participation, social justice leaders should prioritize the participation of teachers, students, other staff, and parents in the decision-making process (Bozkurt, 2017). Simon (1968) indicated that the decision-making process has been at the heart of the administration for the participation dimension of social justice leadership.

Different studies have reported various perceptions on the characteristics of social justice leaders. In his study on the personal characteristics of social justice leaders, Theoharis (2008) asserted that social justice leaders were humble people who question how well what they do and know where they are. They are passionately committed to their profession and see their jobs as a part of their life. Their most distinctive feature is prioritizing the consideration of others rather than themselves. They also encourage their staff to behave similarly. They do not compromise on equality and equity as they have adopted the idea of social justice. McKenzie, et al., (2008) affirmed that school administrators with social justice leadership behaviours work for their stakeholders to have critical awareness. Furman (2012) asserted that social justice leaders display a participatory and democratic attitude in their relations with stakeholders and try to raise the awareness of students and teachers about social inequalities.

\section{Organizational Citizenship Behaviour}

School organizations are composed of communities that both affect and are affected by individuals' behaviours (Sethi \& Compeau, 2002). In this regard, the discipline of organizational behaviour attempts to understand individuals' behaviours and focuses on the 
behaviours exhibited by individuals within the organizational settings (Gürbüz, 2006). It is thorny to change human behaviours, find ways to align them to organizational objectives, and create behavioural changes (Colquitt, LePine, \& Wesson, 2011). It is almost impossible to uncover why people act in a particular manner without understanding the underlying reasons.

In today's world, schools need teachers who voluntarily work for school goals beyond their official job descriptions (Jacobs \& Struyf, 2015; Lohman, 2006). It is hard and may not even be possible to precisely determine the expectations and needs of people through formal rules in advance. George \& Brief (1992) draws attention to uncertainty with the expressions of "Schools cannot predict all of the organizational tasks and definitions in advance in order to achieve their goals; therefore, organizational citizenship behaviours may be inevitable as they are necessary for the effectiveness and efficiency of social organizations such as schools though being beyond the official definition of employees' responsibilities." In this sense, organizational citizenship behaviour emerges as a requirement that should be considered in organizations and schools in particular.

The examination of the literature yields that organizational citizenship behaviour has been among the highly investigated concepts in both international and national settings (Acar, 2006). It can be alleged that the concept of organizational citizenship was based on Barnard's (1938) "unity of collaborative efforts" and Katz's (1964) "extra-role behaviour". However, organizational citizenship behaviour was firstly described by Organ (1988) in the field of management science. Organ (1988) defined it as optional behaviours contributing to the functioning of an organization but are not directly or indirectly included in official job descriptions. Based on Acar's (2006) description, they incorporate voluntary behaviours that have not previously been included or defined in the formal reward system, and their absence does not entail punishment or enforcement. On the other hand, Ehrhart (2004) described them as the behaviours ensuring the effective realization of organizational objectives. Organ (1988) indicated that the particular organizational citizenship behaviours should be dependent on the individual's desire, contribute to the functioning of an organization but should not be included in the reward system.

The literature on organizational citizenship behaviour offers divergent classifications and dimensions. However, no consensus has been reached on its extent. In their study on the classification of organizational citizenship behaviours, Smith, Organ \& Near (1983) defined two different dimensions: altruism, or helping specific persons, and generalized compliance. Organ (1988) put forward a highly referred five-dimensional structure of "altruism, conscience, courtesy, civic virtue and sportsmanship" based on his further studies. On the other hand, Van Dyne \& LePine (1998) divided organizational citizenship behaviour into two categories as assistance and participation. Özdevecioğlu (2003) classified organizational citizenship behaviours as contributing and participating in the organization and avoiding harmful behaviours for the organization. While the individual participates actively in line with the organizational goals for contribution and participation, the primary goal of avoiding harmful behaviours was protecting the organization rather than active participation.

The attempts of individuals working for the organizational goals can be regarded as organizational citizenship behaviours such as assisting their colleagues in the working environment, not complaining about working conditions, participating in the organization's work regularly and voluntarily, having positive thoughts about the organization, and making efforts in this vein. Ehrhart (2004) incorporate working in collaboration with other employees, supporting and helping them, and assisting organizational development among organizational 
citizenship behaviours.

Based on a literature review, it can be alleged that social justice and social justice leadership, which seemed to be ignored both in theory and application, has been emphasized in the field of educational administration since the $21^{\text {st }}$ century (Berkovich, 2014; Furman, 2012; Gümüş, Arar \& Oplatka, 2021; Wang, 2016; Torrance, Forde, King, \& Razzaq, 2021). In cases where social justice leadership practices are exhibited at schools, which are the scenes of educational practices, there are several results in the relevant literature that teachers' organizational adaptation attitudes will develop (Theoharis, 2007), positive attitudes towards school will emerge, school engagement will increase, and teachers' academic optimism will improve (Özdemir \& Pektaş, 2017). However, organizational citizenship behaviours (Özdevecioğlu, 2003; Van Dyne \& LePine, 1998) that are effective in the social functions of organizations such as alturism, participation, helping, cooperation, and support can also be managed efficiently by exhibiting effective social justice leadership behaviours. In this context, it is thought that there is a relationship between social justice leadership and organizational citizenship behaviours. Though the literature was reviewed, no previous study on the relationship between social justice leadership and organizational citizenship behaviour could be found. In this regard, this study is important both in terms of contributing to the growing literature on social justice leadership in the field of educational administration and revealing the relationship between social justice leadership and organizational citizenship behaviours, which has not been studied before.

\section{The Purpose of the Study}

This study aimed to examine the effect of school administrators' social justice leadership behaviours on teachers' organizational citizenship behaviours based on teachers' perceptions. In this regard, the following questions were sought:

(1) To what extent do school administrators exhibit social justice leadership behaviours?

(2) What are teachers' perceptions about exhibiting organizational citizenship behaviours?

(3) Is there a significant correlation between social justice leadership and organizational citizenship behaviours?

(4) Do school administrators' social justice leadership behaviours predict teachers' organizational citizenship behaviours?

\section{Method}

\section{Research Design}

The predictive correlational research design, one of the correlational research methods, was used in the study. The correlational research method is comprised of exploratory and predictive ones in two distinct ways. Exploratory correlational studies attempt to clarify a situation by analysing the relationships between the variables. On the other hand, predictive correlational studies attempt to test direct and indirect relationships between the variables (Frankel \& Wallen, 2006). Structural equation modeling (SEM) was used to reveal the effect of social justice leadership on organizational citizenship behaviour.

\section{Research Sample}

The research sample included 1080 teachers after the exclusion of incomplete and/or incorrect 55 questionnaires. Therefore, statistical analyses were performed on the dataset of 1025 teachers. Simple random sampling was used to determine the research sample. 
Correlational studies necessitate the use of random sampling methods for the significance of the correlation coefficient and the external validity of the study (Frankel \& Wallen, 2006). The demographics of the participants teachers were given in Table 1.

Table 1. Demographics of the research sample

\begin{tabular}{|c|c|c|c|c|c|c|c|}
\hline Variable & & $\mathrm{N}$ & $\%$ & Variable & & $\mathrm{N}$ & $\%$ \\
\hline & Female & 587 & 57,3 & \multirow{4}{*}{ Age Groups } & Between 20-29 & 510 & 49,8 \\
\hline Gender & Male & 438 & 42,7 & & Between 30-39 & 416 & 40,6 \\
\hline \multirow{2}{*}{$\begin{array}{l}\text { Marital } \\
\text { Status }\end{array}$} & Married & 604 & 58,9 & & Between 40-49 & 85 & 8,3 \\
\hline & Single & 421 & 41,1 & & Between 50-65 & 14 & 1,4 \\
\hline \multirow{2}{*}{$\begin{array}{l}\text { Level of } \\
\text { education }\end{array}$} & Undergraduate & 927 & 90,4 & \multirow{3}{*}{$\begin{array}{l}\text { Professional } \\
\text { Seniority }\end{array}$} & Between 1-9 & 723 & 70,5 \\
\hline & Graduate & 98 & 9,6 & & & 259 & 25,3 \\
\hline \multirow{5}{*}{$\begin{array}{l}\text { Number of } \\
\text { children }\end{array}$} & $\begin{array}{l}\text { No Child } \\
1 \text { Child }\end{array}$ & $\begin{array}{l}571 \\
180\end{array}$ & $\begin{array}{l}55,7 \\
17,6\end{array}$ & & Over 20 years & 43 & 4,2 \\
\hline & 2 Children & 207 & 20,2 & \multirow{3}{*}{ Income Range } & $1000-2999 \mathrm{TL}$ & 271 & 26,4 \\
\hline & 3 Children & 50 & 4,9 & & 3000-5999 TL & 513 & 50 \\
\hline & 4 Children & 14 & 1,4 & & $6000-11000 \mathrm{TL}$ & 241 & 23,5 \\
\hline & 5 Children & 3 & 0,3 & \multicolumn{2}{|l|}{ Total } & 1025 & 100 \\
\hline
\end{tabular}

According to Table 1, it was noted that the participating teachers consisted of people with different characteristics as much as possible. The purpose of diversity in the research sample stems from the idea that there may be differences among the opinions of the individuals who make up the social environment of the school within the context of the purpose of the research. This method aims to ensure the diversity of individuals related to the addressed problem through the sample (Yıldırım \& Şimşek, 2018).

\section{Data Collection Tools}

The Social Justice Leadership Scale consisting of 34 items and four dimensions (critical awareness, stakeholder support, participation, and distributive justice) developed by Bozkurt (2017) was used in the study. Cronbach's alpha reliability coefficients were estimated to be ,98 for the overall scale,, 94 for the sub-dimension of critical consciousness, and 95 for the support, participation, and distributive justice sub-dimensions. The 12-item Organizational Citizenship Behaviours Scale developed by DiPaola, Tarter \& Hoy (2005) and adapted into Turkish by Taşdan \& Y1lmaz (2008) was used to determine teachers' level of organizational citizenship behaviours. Tașdan \& Y1lmaz (2008) found .87 Cronbach's alpha reliability coefficient. In this study, Cronbach's alpha reliability coefficient was determined to be, 91 . Within the scope of this research, confirmatory factor analysis was conducted to check the construct validity of the social justice leadership and organizational citizenship behavior scales. The obtained goodness of fit values for social justice leadership; $\mathrm{x} 2 / \mathrm{Sd}=2.42, \mathrm{RMR}=.04, \mathrm{RMSEA}=.06, \mathrm{GFI}=.91$, $\mathrm{TLI}=.91, \mathrm{CFI}=.92, \mathrm{IFI}=.92$, and the agreement obtained for organizational citizenship behavior scale construct validity goodness values were found to be in the range of $\mathrm{x} 2 / \mathrm{Sd}=4.47$, $\mathrm{RMR}=.02, \mathrm{RMSEA}=.05, \mathrm{GFI}=.97, \mathrm{TLI}=.97, \mathrm{CFI}=.98, \mathrm{IFI}=.98$ and at an acceptable level (Çokluk, Şekercioğlu and Büyüköztürk, 2012). 


\section{Data Analysis}

The questionnaire method was used to collect research data. The Social Justice Leadership and the Organizational Citizenship Behaviour Scales along with the personal information form were delivered to the participating teachers. With a view to carrying out the analysis of the data SPSS 22.0 and AMOS 21 software packages programmes were resorted to.

The study included statistical analyses such as arithmetic mean and standard deviation to determine teachers' perception levels of social justice leadership and organizational citizenship behaviour. Correlation analysis was performed to examine the relationships between social justice leadership and organizational citizenship behaviours. According to Büyüköztürk (2013), the Pearson correlation coefficient ranges from +1 to -1 and explains the level and direction of the relationship between two variables. Moreover, coefficients between 0,00 and 0,30 indicate a low level of correlation while those between 0,30 and 0,70 suggest a moderate level of correlation and those between 0,70 and 1,00 intend a high level of correlation.

Structural Equation Modelling (SEM) was used to test the predictive relationship between social justice leadership and organizational citizenship behaviours. Chi-square, Df, Chisquare/Df, RMR, RMSEA, GFI, CFI, NFI, NNFI (TLI), and IFI indices were tested in the structural equation modeling. Kline (2011) states that there is an acceptable fit when the $\mathrm{x}^{2} / \mathrm{Sd}$ is less than two for the goodness of the fit indices observed in the study and used in the structural equation modeling performed with latent variables. Ullman (2001) found that CFI considers the value of freedom in the model, NFI considers the effect of sample size, and IFI considers both sample size and complexity in the model, and all these have an acceptable fit for .90 and over, and a good fit for .95 and over. Byrne (2010) recommends that the RMSEA is independent of the sample size in providing the confidence interval and that this estimate should be below .80 and that the RMR value should be used together with RMSEA to reduce the margin of error.

The options of instruments to measure the teachers' levels of social justice leadership together with its sub-dimensions and organizational citizenship behaviours were (1) Absolutely Disagree between 1,00 and 1,79 points, (2) Disagree between 1,80 and 2,59 points, (3) Partially Agree between 2,60 and 3.39 points, (4) Agree between 3,40 and 4,19 points, (5) Totally Agree between 4,20 and 5,00 points.

\section{Results}

The research data were analysed and reported to find the answers to research problems in line with the purpose of the study. Based on teachers' perceptions, the standard deviation and mean scores of the Social Justice Leadership Scale and its sub-dimensions and the Organizational Citizenship Behaviour Scale were given below.

\section{Results regarding the level of social justice leadership behaviours of school administrators based on teachers' perceptions}

The results of the teachers who participated in the study regarding their perception of social justice leadership behaviour are given in Table 2 . 
Table 2. Standard deviation and mean scores for social justice leadership scale and its subdimensions

\begin{tabular}{llll}
\hline & N & X & SD \\
\hline Social Justice Leadership & 1025 & 3,55 & 0,85 \\
Critical Awareness & 1025 & 3,46 & 1,02 \\
Stakeholder Support & 1025 & 3,63 & 0,84 \\
Participation & 1025 & 3,54 & 0,91 \\
Distributive Justice & 1025 & 3,53 & 1,01 \\
\hline
\end{tabular}

According to Table 2, the perceptions of social justice leadership of participating teachers are at the level of "agree" (X=3,40-4.19). However, the mean of critical awareness $(X=3,46)$ was relatively lower and that of stakeholder support $(X=3,63)$ was higher in terms of the subdimensions.

\section{Results regarding the level of organizational citizenship behaviours of teachers}

The results of the organizational citizenship behaviour perceptions exhibited by the teachers participating in the study are given in Table 3.

Table 3. Standard deviation and mean scores for organizational citizenship behaviours

\begin{tabular}{|c|c|c|c|c|}
\hline & & $\mathrm{N}$ & $\mathrm{X}$ & SD \\
\hline $\begin{array}{l}\text { Organizational } \\
\text { Behaviours }\end{array}$ & Citizenship & 1025 & 3,49 & 0,76 \\
\hline
\end{tabular}

According to Table 3, it is seen that the organizational citizenship behaviour of participating teachers is at the level of "Agree" $(X=3,40-4.19)$. However, the mean was closer to the level of partially agree though it seemed to be high.

Results regarding the relationship between social justice leadership and organizational citizenship behaviour

The findings regarding the relationship between the overall social justice leadership scale and its sub-dimensions and organizational citizenship behaviours were submitted in Table 4.

Table 4. The relationship between social justice leadership and organizational citizenship behaviour

\begin{tabular}{llllllll}
\hline & & $\mathbf{1}$ & $\mathbf{2}$ & $\mathbf{3}$ & $\mathbf{4}$ & $\mathbf{5}$ & $\mathbf{6}$ \\
\hline 1. & Critical Awareness & 1 &, $76^{* *}$ &, $82^{* *}$ &, $72^{* *}$ &, $34^{* *}$ &, $90^{* *}$ \\
2. & Stakeholder Support & & 1 &, $84^{* *}$ &, $73^{* *}$ &, $41^{* *}$ &, $92^{* *}$ \\
3. & Participation & & & 1 &, $79^{* *}$ &, $40^{* *}$ &, $95^{* *}$ \\
4. & Distributive Justice & & & & 1 &, $37^{* *}$ &, $87^{* *}$ \\
5. & Organizational Citizenship Behaviour & & & & & 1 &, $42^{* *}$ \\
6. & Social Justice Leadership & & & & & & 1 \\
\hline$* * \mathrm{p}<0.01$ & & & & & & \\
\hline
\end{tabular}


In Table 4, the relationship between overall social justice leadership and its sub-dimensions and organizational citizenship behaviours was addressed. Accordingly, high level of positive and significant relationships between social justice leadership and its sub-dimensions of critical awareness, stakeholder support, participation and distributive justice were detected $(\mathrm{r}=, 90 ; \mathrm{p}<$ $0,01, r=, 92 ; \mathrm{p}<0,01, \mathrm{r}=, 95 ; \mathrm{p}<0,01, \mathrm{r}=, 87 ; \mathrm{p}<0,01)$. It was observed that there was a moderate, positive, and significant relationship ( $\mathrm{r}=, 42 ; \mathrm{p}<0,01)$ between social justice leadership and organizational citizenship behaviour.

It was determined that there was a moderately positive and significant relationship between organizational citizenship behaviour and the critical awareness, stakeholder support, participation, and distributive justice sub-dimensions of social justice leadership $(\mathrm{r}=, 34 ; \mathrm{p}<$ $0,01, \mathrm{r}=, 41 ; \mathrm{p}<0,01, \mathrm{r}=, 40 ; \mathrm{p}<0,01, \mathrm{r}=, 37 ; \mathrm{p}<0,01)$.

Results regarding the prediction of teachers' organizational citizenship behaviours through school administrators' social justice leadership behaviours

Figures and tables for structural equation modelling non-standardized path coefficients, confirmatory factor analysis fit indices, and structural equation modelling standardized path coefficients for the relationship between social justice leadership and organizational citizenship behaviours were presented below to examine the effect of school administrators' social justice leadership behaviours on teachers' organizational citizenship behaviours.

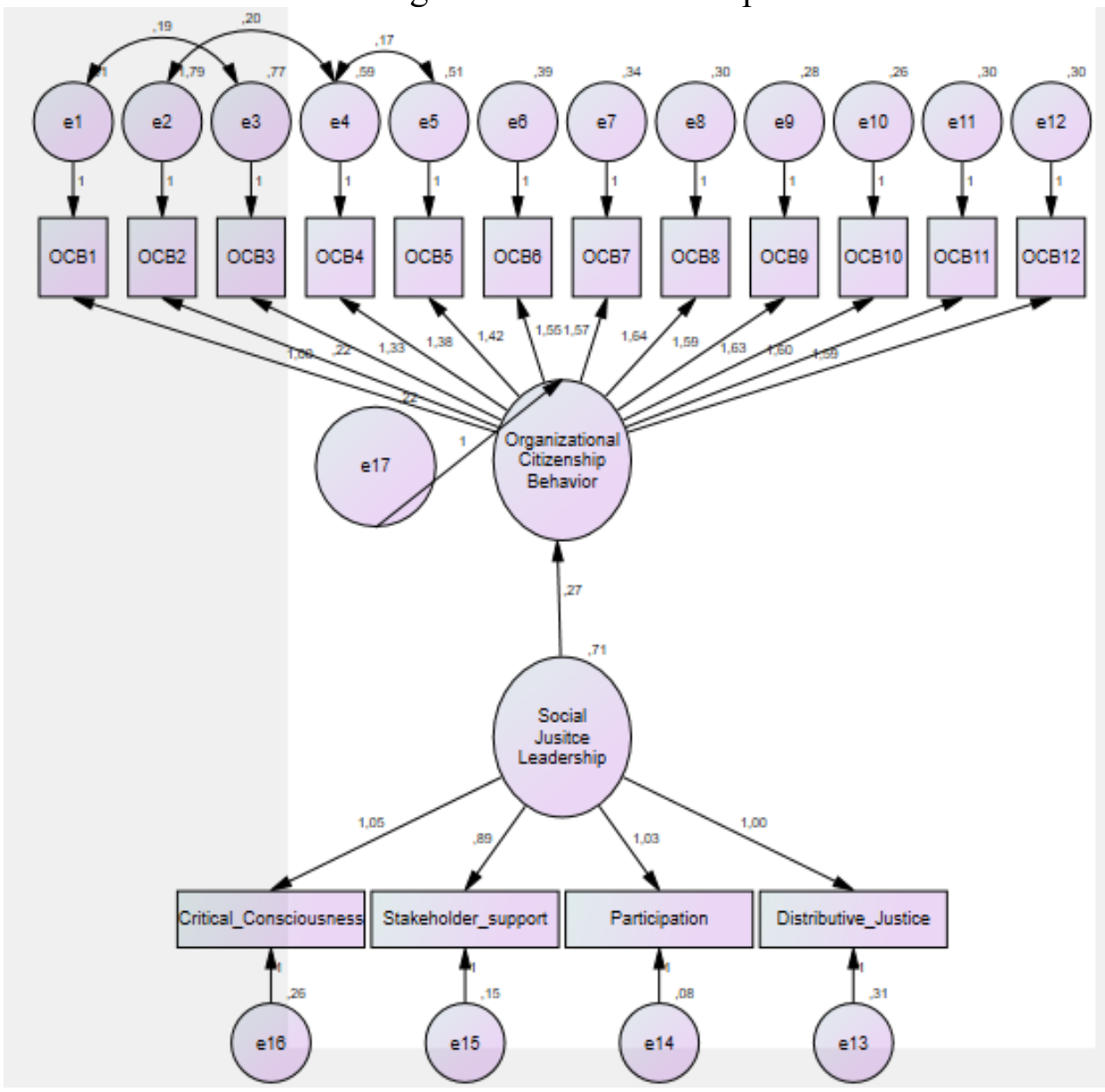

Figure 1. Structural equation modelling non-standardized path coefficients for the relationship between Social Justice Leadership and Organizational Citizenship Behaviours 
Based on Figure 1, the variable of social justice leadership significantly positively predicted the variable of organizational citizenship behaviours $(\beta=, 43 ; p<0,001)$.

Table 5. Confirmatory factor analysis fit indices

\begin{tabular}{llllllllll}
$\chi^{2}$ & DF & $\chi 2 / D F$ & GFI & RMSEA & RMR & CFI & NFI & NNFI(TLI) & IFI \\
\hline 491,706 & 100 & 4,91 &, 93 &, 066 &, 035 &, 96 &, 95 &, 95 &, 96 \\
\hline
\end{tabular}

$* \mathrm{p}<, 001$

It can be alleged that the tested model for the predictor effect of social justice leadership on organizational citizenship behaviours was verified based on the acceptable fit indices (Byrne, 2010; Kline, 2011; Ullman, 2001).

Table 6. Structural equation modelling standardized path coefficients for the relationship between social justice leadership and organizational citizenship behaviour

\begin{tabular}{llll} 
Variables & & Coefficients \\
\hline Organizational Citizenship Behaviour & $\leftarrow$ & Social Justice Leadership &, 61
\end{tabular}

$* \mathrm{p}<0.001 ; \mathrm{R}=, 61$

According to Table 6, it was determined that the social justice leadership behaviours of school administrators explained $37 \%\left(\mathrm{R}^{2}=37,21\right)$ of the variance in teachers' organizational citizenship behaviours.

\section{Discussion and Conclusion}

This study was carried out to investigate the effect of social justice leadership, which has been increasingly discussed in the field of educational sciences after the mid-19 $9^{\text {th }}$ century, and especially after the 2000s in the field of educational administration. For this purpose in mind, the predictor relationship between the social justice leadership behaviours of secondary school administrators and the organizational citizenship behaviours of teachers was scrutinized.

As a result of data analysis, it was determined that the mean of the teachers' perceptions of social justice leadership was relatively higher. It was concluded that the school administrators working at schools under investigation displayed social justice leadership to a great extent. It was also found that the sub-dimensions of social justice leadership were similarly higher as the teachers' agreed with the scale items. In his study based on students' opinions, Özdemir (2017) reported that school administrators exhibited social justice leadership behaviours at a moderate level. In their study based on teachers' opinions, Özdemir \& Pektaş (2017) yielded that school administrators frequently displayed social justice leadership behaviours together with higher levels of creating critical awareness and participation. Bozkurt (2017) established in his social justice leadership scale development study that school administrators mostly performed social justice leadership behaviours. In this regard, it can be alleged that the participating teachers are in the perception that school principals exhibit social justice leadership behaviours to a great extent.

It was found that the organizational citizenship behaviour level of teachers was also higher. In this regard, it can be alleged that teachers had higher levels of perception regarding organizational citizenship behaviours. Accordingly, similar results have been obtained in 
different studies (Gürbüz, 2006; Polat \& Celep, 2008; Gürbüz \& Yüksel, 2008).

It was found that there was a high level of a positive and significant relationship between social justice leadership and its sub-dimensions - critical awareness, stakeholder support, participation, and distributive justice. Özdemir (2017) found a very high level of positive and significant relationship between social justice leadership and support and critical awareness sub-dimensions and a moderate, positive, and significant relationship with the sub-dimension of participation. Özdemir \& Pektaş (2017) discovered that there was a moderately positive and significant relationship between the support sub-dimension of social justice leadership and a higher correlation between the sub-dimensions of critical awareness and participation.

A moderate, positive, and significant relationship between social justice leadership and organizational citizenship behaviours was identified. Organizational citizenship behaviours and the critical awareness, stakeholder support, participation, and distributive justice subdimensions of social justice leadership had moderate, positive, and significant correlations. These findings had common characteristics with different studies elaborating the leadership behaviours of school administrators and organizational citizenship behaviours (Aslan, 2009; Arslantaş \& Pekdemir 2007; Çetin, 2011). In this context, it can be claimed that organizational citizenship behaviours exhibited by teachers will mount as the level of social justice leadership behaviours of school principals increases.

Based on the results of structural equation modeling, it was determined that social justice leadership significantly positively predicted organizational citizenship behaviours. It was established that the tested model for the predictor effect of social justice leadership on organizational citizenship behaviours was verified based on the acceptable fit indices (Byrne, 2010; Kline, 2011; Ullman, 2001; Şimşek, 2017). Moreover, the structural equation modelling standardized path coefficients for the relationship between social justice leadership and organizational citizenship behaviour indicated that social justice leadership explained $37 \%$ of the variance in teachers' organizational citizenship behaviours. This result indicates that there is a relationship between social justice leadership and organizational citizenship behaviours and that they are not independent variables.

The research results stated that social justice leadership was a significant predictor of organizational citizenship behaviours. Therefore, the increase in the social justice leadership behaviours of school administrators may result in the rise of teachers' organizational citizenship behaviours. In this regard, school administrators need to ensure the participation of teachers in the decision-making process about the school and its community, students, parents, other staff, etc (Furman, 2012). Besides, school administrators should appreciate the teachers' differences in language, religion, gender, ethnicity, and ideology as the wealth of schools when deciding inside or outside the school, and they should be able to create an environment of respect and justice (McKenzie et al. 2008). Zellars, Teper \& Duffy (2002) states that the justice practices that include equal pay distribution will boost the organizational citizenship of the employees. It can be asserted that teachers may display more and more organizational citizenship behaviours if the school administrators follow the principles of justice in the distribution of school resources.

This study discussed the relationship between social justice leadership behaviours of school administrators and the organizational citizenship behaviours of teachers. The relationship between social justice leadership and different organizational behaviours can also be scrutinized. Though our study adopted a quantitative research methodology, social justice 
leadership at schools may be probed employing a qualitative research paradigm. Social justice leadership can be examined on different groups of sampling (students, parents, and stakeholders of immediate nature and others ) or in comparison with different variables.

\section{Acknowledgements}

This study is based on the researcher's PhD dissertation entitled "The Relationship among Social Justice Leadership, Loyalty to Administrators and Organizational Citizenship Behaviours".

\section{References}

Acar, Z.A. (2006). Organizational citizenship behavior: it's conceptual development and impacts on individual and organization. Doğuş University Journal, 7(1), 1-14.

Aslantaş, C., \& Pekdemir, I. (2007). An empirical study on the associations among transformational leadership, organizational citizenship behavior and organizational justice. Social Sciences Journal, 1, 261-286.

Aslan, Ş. (2009). The relation of charismatic leadership and organizational citizenship behavior: The role of 'tenure' and 'salary' variables. International Human Sciences Journal, 6(1), 256-276.

Barnard, C.I. (1938). The functıons of executive. Harward University Press.

Bass, M. B. (1999). Two decades of research and development in transformational leadership. European Journal of Work and Organizatıonal Psychology, 8(1), 9-32.

Berkovich, I. (2014). A Socio-ecological framework of social justice leadership in education. Journal of Educational Administration 52(3), 282-309.

Bogotch, I., \& Shields, C.M. (2014). Introduction: Do promises of social justice trump paradigms of educational leadership?. International Handbook of Educational Leadership and Social (In) Justice. New York: Springer.

Bozkurt, B. (2017). A study of developing an assessment tool for social justice leadership behaviors of school principals. Gaziantep University Journal of Social Sciences, 16(3), 721-732. https://doi.org/10.21547/jss.300050

Büyüköztürk, Ş. (2013). Sosyal Bilimler için veri analizi el kitabı [Data analysis handbook for social sciences statistics]. Ankara: Pegem Publishing.

Brooks, J. S., Jean-Marie, G., Normore, A. H., \& Hodgins, D. W. (2007). Distributed leadership for social justice: exploring how influence and equity are stretched over an urban high school. Journal of School Leadership, 17, 378-408.

Brown, M.K. (2004). Leadership for social justice and equity: Weaing a transformative framework and pedagogy. Educational Administration Quarterly, 40(1), 79-110. https://doi.org/10.1177/0013161X03259147

Byrne, B. M. (2010). Structural equation modeling with AMOS. New York: Routledge.

Chen, L.Y. (2008). An Examination of the relationship between leadership behaviour and organizational commitment at steel companies. http://www.huizenga.nova.edu/jame/ examination.htm

Conger, J. A., \& Kanungo, R. N. (1988). Charismatic leadership: The elusive factor in organizational effectiveness. San Francisco: Jossey-Bass.

Çetin, Ş. (2011). Effects of principal leadership and principal-teacher exchange on teachers' organizational citizenship behaviour. (Published Doctoral dissertation). Gazi University Institute of Educational Sciences, Educational Administration and Supervision Department, Ankara. 
Çokluk, Ö., Şekerci, G. \& Büyüköztürk, Ş. (2010). Sosyal bilimler için çok değişkenli istatistik: SPSS ve LISREL uygulamalart[Multivariate statistics for social sciences: SPSS and LISREL applications]. Ankara: Pegem Publishing.

Colquitt, J. A., Lepine, J. \& Wesson, M. J. (2011). Organizational behaviour: improving performance and commitment in the workplace (2nd ed.). NY: McGraw-Hill/Irwin.

DiPaola, M. F., Tarter, C. J., \& Hoy, W. K. (2005). Measuring organizational citizenship in schools: the OCB scale. Educational Leadership and Reform (pp. 319-342). Greenwich, $\mathrm{CN}$ : Information Age.

Ehrhart, M. G. (2004). Leadership and procedural justice climate as antecedents of unit-level organizational citizenship behaviour. Personnel Psychology, 57(1), 61-94.

Falk, R. (2003). Regionalism and world order: the changing global setting. in theories of new regionalism (pp. 63-80). Palgrave Macmillan, London.

Frankel, J.R., \& Wallen, N.E. (2006). How to design and evaluate research in education (6th Ed.). New York: McGraw-Hill Int. Ed.

Freire, P. (2004). Pedagogy of the oppressed. New York: Continuum Press.

Furman, G. C., \& Shields, C. M. (2005). How can educational leaders promote and support social justice and democratic community in schools? In W. A. Firestone\& C. Riehl (Eds.), A new agenda for research in educational leadership. NY: Teachers College Press.

Furman, G. (2012). Social justice leadership as Praxis: Developing capacities through preparation programs. Educational Administration Quarterly, 48(2), 191-229.

George, J. M., \& Brief, A.P. (1992). Feeling good doing good: A conceptual analysis of the moad at work organizational spontaneity relationship. Psychological Bulletin, 112, 310329.

Gewirtz, S., \& Cribb, A. (2002). Plural conceptions of social justice: İmplications for policysociology. Journal of Education Policy, 17(5), 499-509.

Gümüş, S., Arar, K., \& Oplatka, I. (2021) Review of international research on school leadership for social justice, equity and diversity. Journal of Educational Administration and History, 53(1), 81-99. https://doi.org/10.1080/00220620.2020.1862767

Gürbüz, S. (2006). A research on identifying the relationships between organizational citizenship behavior and affective commitment. The International Journal of Economic and Social, 3(2), 48-75.

Gürbüz, S., \& Yüksel, M. (2008). Emotional intelligence in workplace: its relation with job performance, job satisfaction, organizational citizenship behavior, and some demographic factors. Doğuş University Journal, 9(2), 174-190.

Greenleaf, R. K. (1977). Servant Leadership -A Journey into the Nature of Legitimate Power and Greatness. Paulist Press, www.greenleaf.org.

Jacobs, K., \& Struyf, E. (2015). A first step toward a comprehensive model of integrated socioemotional guidance: Investigating the effect of teachers' task perception and a supportive network at school. Journal of Educational Research, 108(2), 95-111. http://doi.org/10.1080/00220671.2013.839542.

Jean-Marie, G. (2008). Leadership for social justice: an agenda for 21 st century schools. The Educational Forum, 72, 340-354.

Karasar, N. (1994). Bilimsel araştırma yöntemi: kavramlar, ilkeler, teknikler [Scientific research method: concepts, principles, techniques], 3A Educational Consulting.

Katz, D. (1964). Motivational basis of organizational behaviour. Behavioral Science, 9 (2), 131146.

Kıral, E. (2015). Decision in management and ethical decision making problematique. Adnan Menderes University Faculty of Education Journal of Educational Sciences, 6(2), 7389. 
Kline, R. B. (2011). Principles and practice of structural equation modeling. New York: The Guilford Press.

Lohman, M. C. (2006). Factors influencing teachers' engagement in informal learning activities. Journal of Workplace Learning, 18(3), 141-156. http://doi.org/10.1108/13665620610654577.

Marshall C. (2004). Social Justice: Challenges to educatıonal admınıstratıon: Introduction to a special 1ssue. Educational Administration Quarterly, 40(1), 5-15. https://doi.org/10.1177/0013161X03258139

Marshall, C., \& Oliva, M. (2006). Leadership for social justice: Making Revolutions in Education, Boston: Pearson Education.

McCabe, N. C., \& McCarthy, M. M. (2005). Educating school leaders for social justice. Educational Policy, 19(1), 201-222.

McKenzie, K. B., Christman, D. E., Hernandez, F., Colleen, E.F, Capper, A., Dantley, M., González, M.N., Cambron-McCabe, N., Scheurich, J.J. (2008). From the Field: A proposal for educating leaders for social justice. Educational Administration Quarterly, 44(1), 111-138.

Oplatka, I. (2010). The place of "social justice" in the field of educational administration: A journal based historical overview of emergent area of study (Ed: Ira Bogotch and Carolyn, M. Shields). International Handbook of Educational Leadership and Social Justice, 1, 15-36. London: Springer.

Organ, D.W. (1988). Organizational citizenship behaviour: The good soldier syndrome. MA: Lexington Books.

Özdemir, M. (2017). Examining the relations among Social Justice Leadership, attitudes towards school and school engagement. Education and Science, 42(191), 267-281.

Özdemir, M., \& Kütküt, B. (2015). Development of social justice leadership scale (SJLS): The validity and reliability study. Journal of Ahi Evran University Kırşehir Education Faculty, 16(3), 201-218.

Özdemir, M., \& Pektaş, V. (2017). Examining the relationship between social justice leadership and school academic optimism according to teachers' opinions. Ege Journal of Education, 18(2), 576-601.

Özdevecioğlu, M. (2003). A research on the relationship between organizational citizenship behavior and some demographic characteristics and academic achievements of university students. Erciyes University Journal of Faculty of Economics and Administrative Sciences, 20, 117-135.

Polat, S., \& Celep, C. (2008). Perceptions of Secondary School Teachers on Organizational Justice, Organizational Trust, Organizational Citizenship Behaviors. Educational Administration: Theory and Practice, 54,307-331.

Rawls, J. (1993). Distributive justice, justice, (Ed: Ryan, A.). Oxford University Press.

Sethi, R., \& Compeau, L. (2002). Social construction, organizational identity, and market orientation of the firm. American Marketing Association, 13, 183-184.

Simon, H. A. (1968). Administrative behavior. The Macmillan Company.

Smith, C. A., Organ, D. W. \& Near, Y. (1983). Organizational citizenship behavior: Its nature and antecedents. Journal of Applied Psychology, 68, 653-663.

Şişman, M. (2006). Democracy and social justice: The untouched myth of Turkish education system. In The Proceedings of the Conference In Search of New Paradigm in Turkish Education System (pp. 291-305).

Şimşek, Ö. F. (2017). Yapısal eşitlik modellemesine giriş: Temel ilkeler ve lisrel uygulamaları [Introduction to structural equation modelling: Fundamentals and lisrel applications]. Ankara: Ekinoks Publishing. 
Taşdan, M., \& Yılmaz, K. (2008). Organizational citizenship and organizational justice scales' adaptation to Turkish. TED Education and Science Journal, 33(150), 87- 96.

Theoharis, G. (2007). Social justice educational leaders and resistance: Toward a theory of social justice leadersip. Educational Administration Quarterly, 43(2), 221-258.

Theoharis, G. (2008). Woven in deeply: Identity and leadership of urban social justice principals. Education and urban society, 41(1), 3-25.

Torrance, D., Forde, C., King, F., \& Razzaq, J. (2021). What is the problem? A critical review of social justice leadership preparation and development. Professional Development in Education, 47(1), 22-35.

Turhan, M. (2007). The Effect of Ethical Leadership Behaviors of High School and Vocational High School Principals on Social Justice in Schools, (Published Doctoral dissertation). Firat University Social Sciences Enstitüe. Elaziğ.

Ullman, J.B. (2001). Structural equation modeling. In B. Tabachnick \& L.S. Fidell (Eds.), Using multivariate statistics ( ${ }^{\text {th }}$ ed.). Boston: Allyn \& Bacon.

Van Dyne, L., \& LePine, J. A. (1998). Helping and voice extra-role behaviors: evidence of construct and predictive validity. Academy of Management Journal, 41(1), 108-119.

Wang, F. (2016). From redistribution to recognition: How school principals perceive social justice. Leadership and Policy in Schools 15(3), 323-342.

Wasonga, T. A. (2009. Leadership practices for social justice, democratic community and learning: school principals' perspectives. Journal of School Leadership, 19, 200-224.

White, R. E., \& Cooper, K. (2014). Towards an understanding of social justice in our schools: globalization, inclusive leadership and the transformation of schooling. In International handbook of educational leadership and social (in) justice (pp. 1063-1079). Springer, Dordrecht.

Yıldırım, A., \& Şimşek, H. (2018). Sosyal bilimlerde nitel araştırma yöntemleri [Qualitative Research Methods in Social Sciences] (11th Ed.). Ankara: Seçkin Publishing.

Yukl, G. (2010). Leadership in organizations (7th Eds.). London: Pearson.

Zellars, K.L., Teper, B.J., \& Duffy, M.K. (2002), Abusive supervision and subordinates' organizational citizenship behavior. Journal of Applied Psychology, 87(6), 1068-1076. 